UDC 541.64:547.5644

\title{
SYNTHESIS AND SPECTROSCOPIC CHARACTERIZATION OF Fe(III), Mn(II) AND Cu(II) COMPLEXES WITH N'-MALEOIL-SALICYLIC-HYDRAZID
}

\author{
${ }^{1}$ G.H. Gondolova, ${ }^{2}$ A.A. Medjidov, ${ }^{2}$ P.A. Fatullayeva, ${ }^{2}$ A.I. Israfilov \\ ${ }^{1}$ Institute of Ecology and Natural Resources \\ Ganja Branch of the National Academy of Sciences of Azerbaijan \\ H.Aliyev Avenue, 153, AZ 2003 Ganja, Azerbaijan; e-mail: gulnargondolova@gmail.com \\ ${ }^{2}$ Acad. M. Nagiyev Institute of Catalysis and Inorganic Chemistry \\ National Academy of Sciences of Azerbaijan \\ AZ 1143 Baku, H. Javid Avenue, 113, Azerbaijan
}

\begin{abstract}
$\left[\mathrm{Fe}\left(\mathrm{C}_{11} \mathrm{H}_{9} \mathrm{~N}_{2} \mathrm{O}_{5}\right)_{2}\left(\mathrm{H}_{2} \mathrm{O}\right)_{2}\right] \cdot 3\left(\mathrm{C}_{3} \mathrm{H}_{7} \mathrm{NO}\right)(\mathrm{1}),\left[\mathrm{Mn}\left(\mathrm{C}_{11} \mathrm{H}_{9} \mathrm{~N}_{2} \mathrm{O}_{5}\right)_{2}\left(\mathrm{H}_{2} \mathrm{O}\right)_{2}\right] \cdot 3\left(\mathrm{C}_{3} \mathrm{H}_{7} \mathrm{NO}\right)$ (2) and $\left[\mathrm{Cu}\left(\mathrm{C}_{11} \mathrm{H}_{9} \mathrm{~N}_{2} \mathrm{O}_{5}\right)_{2}\left(\mathrm{H}_{2} \mathrm{O}\right)_{2}\right] \cdot 3\left(\mathrm{C}_{3} \mathrm{H}_{7} \mathrm{NO}\right)(3)$ complexes have been synthesized and characterized by elemental analysis, FT-IR and EPR spectra, magnetic susceptibility and thermal analysis. All complexes show distorted octahedral geometry. In 1, 2 and 3complexes, metal ions are coordinated by means of two oxygen atoms of salicylic residue and two nitrogen atoms bonded with maleic residue and two water molecules.
\end{abstract}

Keywords: synthesis, $\mathrm{Fe}(I I I), \mathrm{Mn}$ (II) and Cu(II) complexes, thermal behavior, magnetic properties

\section{Introduction}

Hydrazides of carboxylic and dicarboxylic acids are of theoretical and practical interest. An emphasis laid on these compounds is due, first of all, to their ability to change the dentation depending on reaction conditions and form both mononuclear and polynuclear complexes. N'-acylsalicylhydrazides contain two or three nitrogen and oxygen donor atoms which can coordinate with metal atoms and give rise to various structural types such as trinuclear polymer [1], hexanuclear, octanuclear, decanuclear and dodecanuclear metalladiazamacrocycles [2-4].

At present, quite a lot of theoretical and experimental data have been accumulated on the physical-chemical properties, composition and structural features of transition metal complexes. This is due to the fact that many of their coordination compounds have high physiological activity to serve as a basis for creating promising materials. In particular, they are based on characteristic hydrazides complexes TB [5-6], anticancer [7-9], antimalaria [10] and antimicrobial [11-12] activity and bactericidal, fungicidal, and antiviral [13] effect.

The aim of our work is to search for ligands that form polynuclear complexes. With that end in view, we synthesized a N'acylsalicylhydrazide ligand [(2-hydroxybenzoyl) of hydrazinyl]-4-oxobut-2-enoic acid $\left(\mathrm{H}_{4} \mathrm{~L}\right)$ by means of the method [14] based on the following: it is a potential heptadentate ligand with $-\mathrm{OH},-\mathrm{COOH}$ and -CONHNHCOwhich can construct multinuclear coordination polymers with transition metals. However, as shown in the work, this compound together with $\mathrm{Fe}(\mathrm{III}), \mathrm{Mn}$ (II) and $\mathrm{Cu}$ (II) ions behave as a bidentate monoanionic ligand.

\section{EXPERIMENTAL}

\subsection{Measurements}

Note that IR spectra were recorded on a NicoletIS10 Spectrometer using $\mathrm{KBr}$ discs in the range 4000-400 $\mathrm{cm}^{-1}$. The ${ }^{1} \mathrm{H}$ and ${ }^{13} \mathrm{CNMR}$ spectra were obtained on a
BrukerDPX-400 Spectrometer using MeODsolvent at $300 \mathrm{~K}$. Magnetic moments at $25^{\circ} \mathrm{C}$ were determined using the Faraday method with $\mathrm{Hg}\left[\mathrm{Co}(\mathrm{SCN})_{4}\right]$ as calibrant. 


\subsection{Synthesis of $\mathrm{H}_{4} \mathrm{~L}$ (N'-maleoyl-salicylic hydrazide)}

Salicylhydrazide was synthesized according to the literature procedure.

Maleic anhydride $(0.981 \mathrm{~g}, 10 \mathrm{mmol})$ was added to the solution of methanol $(40 \mathrm{~mL})$ with salicylhydrazide $(1.52 \mathrm{~g}, 10.0 \mathrm{mmol})$ at room temperature. The reaction mixture was stirred. The reaction was over in a short time $(5 \sim 10 \mathrm{~min})$ with higher yields. The white crystalline product was washed with methanol, and dried on air. The purity of the ligand was checked by IR spectra, and melting point. Yield: $95 \%$ m.p. $188^{\circ}$ C; Found: C, 52.8; H, 4; $\mathrm{N}, 11.2 \%$. Anal. Calcd. for: $\mathrm{C}_{11} \mathrm{H}_{10} \mathrm{O}_{5} \mathrm{~N}_{2} \mathrm{C}$,
53.4; H, 4.2; N, $10.8 \% .{ }^{1} \mathrm{H}$ NMR (MeOD), $\delta$ ppm: $\quad 7.92 \quad(\mathrm{~d}, \quad 1 \mathrm{H}, \quad \mathrm{o}-\mathrm{PhCH})$; 7.467.43(m,1H;p-PhCH), 6.98-6.96(m, 2H m$\mathrm{PhCH}), 6.41-6.39(\mathrm{~m}, 2 \mathrm{H} ;-\mathrm{CH}=\mathrm{CH}-) ;{ }^{13} \mathrm{C}$ NMR (MeOD), $\delta$ ppm:166.92 (-COOH-), 166.03 (-CO-PA), 163.54 (Ph-CO-), 158.53 $(\mathrm{PhC}-\mathrm{OH}), \quad 134.01(-\mathrm{NHCO}-\mathrm{CH}=), 131.76 \quad(\mathrm{p}-$ $\mathrm{PHC}), 129.94\left(=\mathrm{CH}_{-\mathrm{COOH}}\right), 128.82$ (o-PhC), 119.25 (m-Ph), 116.77 (PhC-CO-), 114.74 (m$\mathrm{PhC}_{-\mathrm{C}-\mathrm{OH}}$ ); IR (KBr pellet, cm-1): $v \mathrm{~N}-\mathrm{H}$, 3029vs; broad; $v \mathrm{C}=\mathrm{O}, 1704 \mathrm{~s} ; \mathrm{vC}=\mathrm{C}, 1659 \mathrm{~s}$; $v \mathrm{C}=\mathrm{N}, \quad 1610 \mathrm{~s} ; \quad v \mathrm{NC}=\mathrm{O}, 1525 \mathrm{vs} ; \delta \mathrm{N}-\mathrm{H}$, 1490vs; vC-OH (phenolic), 1228 s, $1160 \mathrm{~s}$.

\subsection{Synthesis of complexes}

\subsubsection{Synthesis of $\left[\mathrm{Fe}\left(\mathrm{H}_{3} \mathrm{~L}\right)_{2} \cdot 2 \mathrm{H}_{2} \mathrm{O}\right] \cdot 3 \mathrm{DMF}$}

Solution of $\mathrm{H}_{4} \mathrm{~L}(0.25 \mathrm{~g}, 0.1 \mathrm{mmol})$ in methanol and DMF $(2: 1)$, and solution of $\mathrm{FeCl}_{3}(0.135 \mathrm{~g}, 0.05 \mathrm{mmol})$ in methanol were mixed and stirred for $0.5 \mathrm{~h}$. Then the solution obtained was adjusted to $\mathrm{pH}=8-9$ by $\mathrm{NH}_{4} \mathrm{OH}$.
Further, the solution was stirred for $1 \mathrm{~h}$ and filtered. After slow evaporation of the mother solution within a month, a dark brown precipitate of 1 was obtained from the filtrate in $45 \%$ yield.

\subsubsection{Synthesis of $\left[\mathrm{Mn}\left(\mathrm{H}_{3} \mathrm{~L}\right)_{2} \cdot 2 \mathrm{H}_{2} \mathrm{O}\right] \cdot 3 \mathrm{DMF}$}

The complex was prepared in a manner similar to that used for 1; a brown precipitate was obtained in 55\% yield.

\subsubsection{Synthesis of $\left[\mathrm{Cu}\left(\mathrm{H}_{3} \mathrm{~L}\right)_{2} \cdot 2 \mathrm{H}_{2} \mathrm{O}\right] \cdot 3 \mathrm{DMF}$}

The complex was prepared in a manner similar to that used for 1; a dark green precipitate was obtained in $62 \%$ yield.

\section{RESULTS AND DISCUSSION}

The ligand $\mathrm{H}_{4} \mathrm{~L}$ was obtained by a method different from the one known in literature [10], under relatively mild conditions by reaction of salicylhydrazide with maleic anhydride in a methanol solution. The structure of the prepared hydrazide ligand was studied by elemental analyses, IR, and ${ }^{1} \mathrm{H}$ and ${ }^{13} \mathrm{C}$ NMR spectral studies. The results obtained are in good agreement with those calculated for the suggested formula, and the melting point is sharp indicating the purity of the prepared ligand $\left(\mathrm{H}_{4} \mathrm{~L}\right)$ (Scheme 1.). 


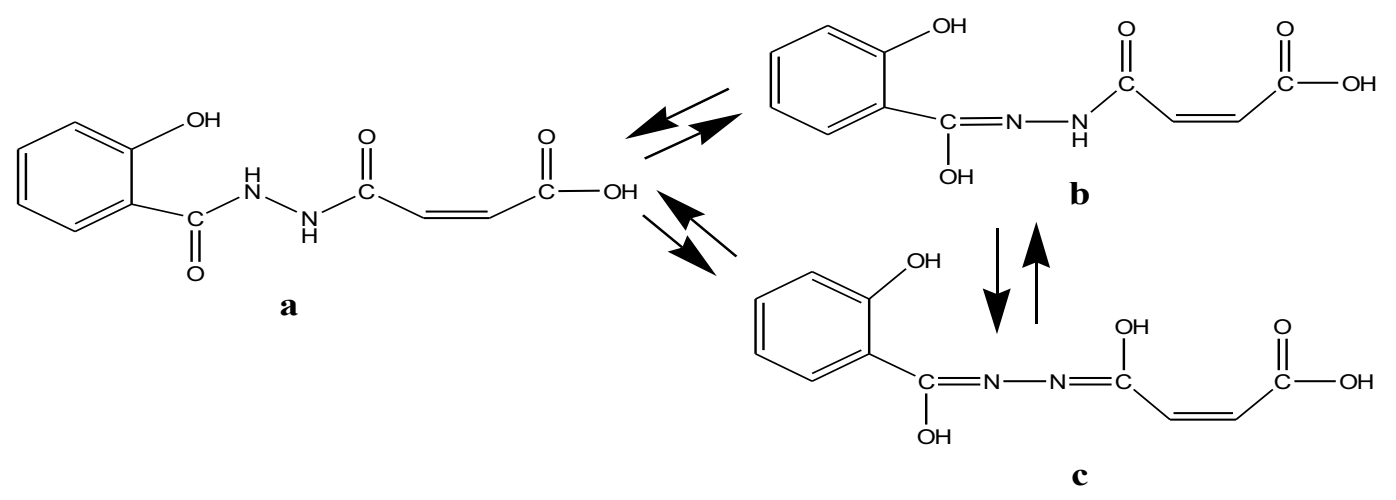

Scheme 1. $H_{4} L$ a-diketo-form, $\boldsymbol{b}$-mono-enol form, $\boldsymbol{c}$-dienol form

\subsection{Spectral characterization}

Note that the IR spectra of involves the oxygen of the carbonyl group of thehydrazide ligand contain a strong $\mathrm{C}=\mathrm{O}$ the salicylic residue and the nitrogen atom absorption band at $1704 \mathrm{~cm}^{-1}$ and $\mathrm{N}-\mathrm{H}$ bonded with the maleic residue. Deprotonation absorption band at $3029 \mathrm{~cm}^{-1}$. Bands at 1228 and coordination can also be confirmed by $\mathrm{cm}^{-1}$ is assigned to the stretching vibration of band at 524-534 $\mathrm{cm}^{-1}$ (M-O bonds) and 406$v(\mathrm{Ph}-\mathrm{O})$. For all complexes, the absence of $466 \mathrm{~cm}^{-1}$ (M-N bonds) respectively. Note that stretching band $\mathrm{N}-\mathrm{H}$ and $\mathrm{C}=\mathrm{O}$ is consistent with deprotonation of $\mathrm{CONH}$ groups and coordination with metal ions in enol form. Also, the characteristic absorptions at $1607 \mathrm{~cm}^{-}$ 1 indicate the presence of $\mathrm{C}=\mathrm{N}-\mathrm{N}=\mathrm{C}$ group the absence of carboxyl absorption band is explained by the formation of strong intermolecular hydrogen bonds due between of $\mathrm{O}$ (carboxyl group) and $\mathrm{H}$ (phenolic), $\mathrm{O}$ (carboxyl group) and $\mathrm{H}$ (crystallization water).

(scheme 1-c). The complexing process

\subsection{Elemental analysis}

Elemental analysis data show that $\mathrm{Fe}^{2+}, \mathrm{Mn}^{2+}$ ion and $\mathrm{LH}_{3}$ is the singly ionized ligand). and $\mathrm{Cu}^{2+}$ ions form complexes of the Fig. 1. composition $\mathrm{M}\left(\mathrm{LH}_{3}\right)_{2}$ (where $\mathrm{M}$ is the metal<smiles>O=C(O)/C=C/C(=O)N[C@]1(O)OC(c2ccccc2O)=NN1C(=O)/C=C/C(=O)O</smiles>

Fig. 1 The structure of complexes 


\subsection{Thermal Analysis (TG)}

Thermogravimetric analysis showed that the decomposition of compounds occurs in two stages. The main weight loss occurs at the first stage within the temperature range $250-350^{\circ} \mathrm{C}(55-75 \%$, depending on the nature of metal ion); at the second stage within the temperature range of $400-600^{\circ} \mathrm{C}$; the final decomposition takes place to form appropriate oxides. Note that the amount of oxides remaining after the decomposition corresponds to the content of metals in the complexes (Table 1).

Table 1. Some characteristics of synthesized compounds

\begin{tabular}{|c|c|c|c|c|c|c|c|c|}
\hline \multirow[t]{2}{*}{ Compounds } & \multirow[t]{2}{*}{ Brutto-formula } & \multirow[t]{2}{*}{$\mathrm{T}_{\mathrm{m}},{ }^{0} \mathrm{C}$} & \multicolumn{5}{|c|}{$\begin{array}{c}\text { Elemental analysis, \% } \\
\text { Calc./anal. }\end{array}$} & \multirow[t]{2}{*}{$\begin{array}{l}\mathrm{M}_{\mathrm{r}} \\
\mathrm{q} \backslash \mathrm{mol}\end{array}$} \\
\hline & & & $\mathrm{C}$ & $\mathrm{H}$ & $\mathrm{N}$ & $\mathrm{O}$ & $\mathrm{M}$ & \\
\hline \multirow[b]{2}{*}{$\mathrm{I}$} & \multirow[b]{2}{*}{$\mathrm{C}_{11} \mathrm{H}_{10} \mathrm{O}_{5} \mathrm{~N}_{2}$} & \multirow[b]{2}{*}{188} & 53.4 & 4.2 & 10.81 & 31.59 & - & \multirow[t]{2}{*}{250} \\
\hline & & & 52.8 & 4 & 11.2 & 32 & - & \\
\hline \multirow[b]{2}{*}{ II } & \multirow{2}{*}{$\mathrm{C}_{22} \mathrm{H}_{18} \mathrm{O}_{10} \mathrm{~N}_{4} \mathrm{Fe}$} & \multirow{2}{*}{$>260$} & 47.65 & 3.25 & 10.11 & 28.88 & 10.11 & \multirow{2}{*}{554} \\
\hline & & & 47.45 & 3.28 & 10.02 & 27.87 & 11.38 & \\
\hline \multirow[b]{2}{*}{ III } & \multirow[b]{2}{*}{$\mathrm{C}_{22} \mathrm{H}_{18} \mathrm{O}_{10} \mathrm{~N}_{4} \mathrm{Mn}$} & \multirow[b]{2}{*}{$>260$} & 47.75 & 3.26 & 10.13 & 28.93 & 9.93 & \multirow[b]{2}{*}{552.9} \\
\hline & & & 47.72 & 3.34 & 9.49 & 28.23 & 11.22 & \\
\hline \multirow[t]{2}{*}{ IV } & \multirow[t]{2}{*}{$\mathrm{C}_{22} \mathrm{H}_{18} \mathrm{O}_{10} \mathrm{~N}_{4} \mathrm{Cu}$} & \multirow[t]{2}{*}{$>260$} & 46.98 & 3.21 & 9.96 & 28.47 & 11.38 & \multirow[t]{2}{*}{562} \\
\hline & & & 47.01 & 3.18 & 9.89 & 28.28 & 11.64 & \\
\hline
\end{tabular}

\subsection{EPR spectra}

The EPR spectra of all complexes in the polycrystalline state are practically symmetrical singlet indicating a high degree of symmetry around the metal ion close to the octahedral one. The intense signals observed in iron and manganese complexes are manifest on high-spin ${ }^{6} \mathrm{~S}$ ground state of $\mathrm{Fe}(\mathrm{III})$ ions
( $\mathrm{d}^{5}$-configuration) and $\mathrm{Mn}(\mathrm{II})$. The values of $\Delta \mathrm{H}$ and g-factors for complexes $\mathbf{1}$ and $\mathbf{2}$ have values of $\Delta \mathrm{H}=1400 \mathrm{G}$ and $\Delta \mathrm{H}=800 \mathrm{G}$ and $\mathrm{g}$ $=2.02$ and $g=2.014$ respectively. As for the $\mathrm{Cu}$ (II) complex (3), the line width peak to peak is $\Delta \mathrm{H}=350 \mathrm{G}$, and the g-factor is 2.12.(fig.2).

\subsection{Magnetic susceptibility}

The iron complex shows the value of the magnetic moment equal to 5.71 B.M. at room temperature, manganese - 5.90 B.M, and copper - 1.9 B.M. It revealed that the complexes have magnetic moments in the normal range typical for octahedral complexes. 


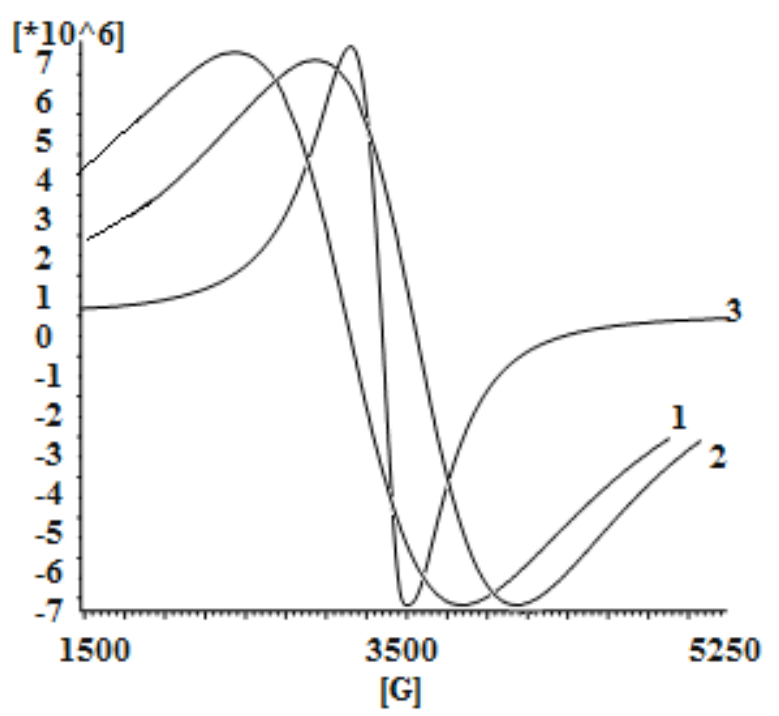

Fig.2 EPR spectra of complexes 1, 2, and 3.

\section{CONCLUSION}

$\left[\mathrm{Fe}\left(\mathrm{H}_{3} \mathrm{~L}\right)_{2} \cdot 2 \mathrm{H}_{2} \mathrm{O}\right] \cdot 3 \mathrm{DMF},\left[\mathrm{Mn}\left(\mathrm{H}_{3} \mathrm{~L}\right)_{2} \cdot 2 \mathrm{H}_{2} \mathrm{O}\right] \cdot 3$ DMF and $\left[\mathrm{Cu}\left(\mathrm{H}_{3} \mathrm{~L}\right)_{2} \cdot 2 \mathrm{H}_{2} \mathrm{O}\right] \cdot 3 \mathrm{DMF}$ have been prepared on the basis of N'-maleoyl-salicylic hydrazide and characterized by elemental analysis, FT-IR,magnetic susceptibility and thermal analysis. It found that the ligand behaves as a monoanionicbidentate where the ligand is in the enol form and coordinates with metal ions through the oxygen atoms of salicylic residue and nitrogen atom bonded with maleic residue.

\section{REFERENCES}

1. Moon D., Song J., Kim B.J. et al. A novel 18-metallacrown-6 complex: Synthesis, structural characterization and magnetic properties. Inorg.Chem. 2004. vol. 11, no. 11, pp. 1919. doi.org/10.1016/j.solidstatesciences. 2009. 07.014

2. Lin S., Liu S.X., Chen Z. et al. Synthesis, Structure and Magnetism of a Ferric 24-Azametallacrown-8 Complex. Inorg.Chem. 2004, vol.11, no. $11, \quad$ pp. 2222. DOI: $10.1021 / \mathrm{ic} 035145 \mathrm{w}$

3. John R.P., Lee K., Suh B.J. et al. Modulation of the Ring Size and Nuclearity of Metallamacrocycles via the Steric Effect of Ligands: Preparation and Characterization of 18 Membered Hexanuclear, 24-Membered Octanuclear, and 30-Membered
Decanuclear Manganese Metalladiazamacrocycles with $\alpha-$ and $\beta$ Branched $N$-Acylsalicylhydrazides. Inorg.Chem. 2005, vol. 44, no. 20, pp. 7109. DOI: $10.1021 / \mathrm{ic} 050891 \mathrm{~h}$

4. John R.P., Park J., Moon D. et al. Encapsulation of a guest molecule in a strained form: an extended 36membered dodecanuclear manganese metallamacrocycle that accommodates a cyclooctane in the $S_{4}$ symmetry conformation. Chem. Commun. 2006, pp. 3699. DOI: 10.1039/B607675K

5. Patole J., Sandbhor U., PadhyeS. et al. Structural chemistry and In vitro antitubercular activity of acetylpyridine benzoyl hydrazone and its copper complex against Mycobacterium smegmatis. Bioorg. Med. Chem. Let. 2003, vol. 13, no. 1, pp. 51. 
doi.org/10.1016/S0960-894X(02) 00855-7

6. Terzioğlu N., Gürsoy A. Synthesis and anticancer evaluation of some new hydrazone derivatives of 2,6dimethylimidazo[2,1- $b][1,3,4]$ thiadiazole-5-carbohydrazide. Eur. J. Med.Chem. 2003, vol. 38, no. 2, pp.781. doi.org/10.1016/S02235234(03)00138-7

7. Cocco M.T., Congiu C., Lilliu V., Onnis V. Synthesis and in vitro antitumoral activity of new hydrazinopyrimidine-5-carbonitrile derivatives. Bioorganic \& medicinal chemistry. 2006, vol. 14, no. 2, pp. 366.

doi.org/10.1016/j.bmc.2005.08.012

8. Easmon J., Puerstinger G., Roth T. et al. 2-Benzoxazolyl and 2benzimidazolyl hydrazones derived from 2-acetylpyridine: A novel class of antitumor agents. Int. J. of Canser. 2001, vol. 94, no. 1, pp. 89. DOI: $10.1002 /$ ijc. 1427

9. Walcourt A., Loyevsky M., Lovejoy D.B. et al. Novel aroylhydrazone and thiosemicarbazone iron chelators with anti-malarial activity against chloroquine-resistant and -sensitive parasites. International Journal of Biochemistry and Cell Biology. 2004, vol. 36, no. 3, pp. 401. doi.org/10.1016/S1357-2725(03) 00248-6

10. Vicini P., Zani F., Cozzini P., Doytchinova I. Hydrazones of 1,2- benzisothiazole hydrazides: synthesis, antimicrobial activity and QSAR investigations. Eur J Med Chem. 2002, vol. 37, no. 7, pp. 64. PMID:12126774

11. Shunsheng Zhao, Sijiao Wang, Xiangrong Liu et al. Synthesis, crystal structures, and selected properties of $\mathrm{Cu}(\mathrm{II})$ and $\mathrm{Zn}(\mathrm{II})$ complexes with in situ formed 2-hydroxy-N'-(propan-2ylidene) benzohydrazide. Journal of Coordination Chemistry. 2012, vol. 65, no. 24, pp. 4277. doi.org/10.1080/ 00958972.2012 .738813

12. Ming-Li Liu, Jian-Min Dou, Da-Cheng $\mathrm{Li}$ et al. Synthesis, structural characterization and thermal properties of three copper(II) complexes based on aryl hydrazide ligands. Transition Met.Chem. 2012, vol. 37, no. 1, pp. 117.

13. Dacheng Li, Suna Wang, Hui Xu, Yan Yang, Suyuan Zeng, Jinsheng Zhao, Daqi Wang, Jianmin Dou. Supramolecular architectures based on di-, tri- and tetrameric complexes with $N, N^{\prime}$-diacylhydrazide ligands. Inorganica Chimica Acta. 2010, vol. 365, pp. 85. doi.org/10.1016/j.ica. 2010.08.032

14. Handong Yin, Jichun Cui, Yanling Qiao. The first 1D tetranuclear organotin (IV) complex with $N^{\prime}$ acylsalicylhydrazide: Synthesis, characterization and crystal structure. Inorganic Chemistry Communications. 2008, vol. 11, no. 6, pp. 684 doi.org/10. 1016/j.inoche.2008.03.010

\section{N'-MALEOIL-SALISILHIDRAZID IL KOMPLEKSLORININ SINTEZI VO SPEKTROSKOPIK XÜSUSIYYYOTLORI}

${ }^{1}$ G.H. Qondolova, ${ }^{2}$ Ә.Ә. Mocidov, ${ }^{2}$ P.Ө. Fotullayeva, ${ }^{2}$ A.İ. İsrafilov

${ }^{1 *}$ AMEA Ganca bölmasi, Ekologiya va Tabii Ehtiyyatlar Institutu, Azarbaycan, Gəncə ş., H. Oliyev pr-ti, 153, AZ 2003

${ }^{2}$ AMEA akad. M.F. Nağlyev adına Kataliz va Qeyri-üzvi Kimya Institutu Azorbaycan, Baki ş., H.Cavid pr-ti, 113, AZ 1143, e-mail: gulnargondolova@gmail.com 
$\left.\mathrm{Fe}\left(\mathrm{C}_{11} \mathrm{H}_{9} \mathrm{~N}_{2} \mathrm{O}_{5}\right)_{2}\left(\mathrm{H}_{2} \mathrm{O}\right)_{2}\right] \cdot 3\left(\mathrm{C}_{3} \mathrm{H}_{7} \mathrm{NO}\right) \quad$ (1), $\quad\left[\mathrm{Mn}\left(\mathrm{C}_{11} \mathrm{H}_{9} \mathrm{~N}_{2} \mathrm{O}_{5}\right)_{2}\left(\mathrm{H}_{2} \mathrm{O}\right)_{2}\right] \cdot 3\left(\mathrm{C}_{3} \mathrm{H}_{7} \mathrm{NO}\right) \quad$ (2) va $\left[\mathrm{Cu}\left(\mathrm{C}_{11} \mathrm{H}_{9} \mathrm{~N}_{2} \mathrm{O}_{5}\right)_{2}\left(\mathrm{H}_{2} \mathrm{O}\right)_{2}\right] \bullet 3\left(\mathrm{C}_{3} \mathrm{H}_{7} \mathrm{NO}\right)$ (3) komplekslari sintez edilmiş vo element analizi, IQ $\mathrm{Q}$ - vo EPR spektroskopiya, maqnit hassaslığ va termiki analiz vasitaləri ila tadqiq edilmişdir. Bütün komplekslar təhrif edilmiş oktaedrik quruluş amala gatirir. 1, 2 va 3 komplekslarinda metal ionları iki liqand molekulunun salisil qalığının oksigen atomu, malein qalığl ilo birloşmiş azot atomu va iki molekul su ila koordinasiya olunur.

Açar sözlor: sintez, $\mathrm{Fe}(I I I), \mathrm{Mn}$ (II) va Cu(II) kompleksləri, termiki analiz, maqnit həssaslığ

\title{
СИНТЕЗ И СПЕКТРОСКОПИЧЕСКИЕ ХАРАКТЕРИСТИКИ КОМПЛЕКСОВ Fe(III), Mn(II) И CИ(II) C N’-МАЛЕОИЛ-САЛИЦИЛГИДРАЗИДОМ
}

\author{
${ }^{1}$ Г.Г. Гондолова, ${ }^{2}$ А.А. Меджидов, ${ }^{2}$ П.А. Фатуллаева, ${ }^{2}$ А.И. Исрафилов \\ ${ }^{1}$ Институт Экологии и Природных запасов, Гянджинское отделение НАНА \\ Азербайджан, AZ 2003 г. Гянджа, пр-т Г.Алиева, 153 \\ ${ }^{2}$ Институт Катализа и Неорганической химии им. акад. М.Ф.Нагиева, НАНА \\ Азербайджан, AZ 1143 г. Баку, пр-т Г.Джавида, 113 \\ E-mail: gulnargondolova@gmail.com
}

Были синтезированы комплексы $\left.\mathrm{Fe}\left(\mathrm{C}_{11} \mathrm{H}_{9} \mathrm{~N}_{2} \mathrm{O}_{5}\right)_{2}\left(\mathrm{H}_{2} \mathrm{O}\right)_{2}\right] \cdot 3\left(\mathrm{C}_{3} \mathrm{H}_{7} \mathrm{NO}\right) \quad$ (1), $\left[\mathrm{Mn}\left(\mathrm{C}_{11} \mathrm{H}_{9} \mathrm{~N}_{2} \mathrm{O}_{5}\right)_{2}\left(\mathrm{H}_{2} \mathrm{O}\right)_{2}\right] \cdot 3\left(\mathrm{C}_{3} \mathrm{H}_{7} \mathrm{NO}\right) \quad$ (2) $u \quad\left[\mathrm{Cu}\left(\mathrm{C}_{11} \mathrm{H}_{9} \mathrm{~N}_{2} \mathrm{O}_{5}\right)_{2}\left(\mathrm{H}_{2} \mathrm{O}\right)_{2}\right] \cdot 3\left(\mathrm{C}_{3} \mathrm{H}_{7} \mathrm{NO}\right) \quad$ (3) $u$ охарактеризованы элементным анализом, ИК- и ЭПР спектрами, магнитной восприимчивостью и термическим анализом. Все комплексы показывают искаженную октаэдрическую геометрию. В комплексах 1,2 и 3 ионы металлов координируются с двумя молекулами лиганда посредством двух атомов кислорода салицилового остатка, двух атомов азота, связанных с малеиновым остатком и двумя молекулами воды.

Ключевые слова: синтез, комплексы Fе(III), Mn (II) и Си(II), магнитная восприимчивость, термический анализ.

Received 12.01.2018. 